\section{Deadly mushrooms}

\section{Feux Follets et Champignons \\ Nucléaires}

by Georges Charpak and Richard L. Garwin Editions Odile Jacob: 1997. Pp. 382 . FF150

\section{Hubert Curien}

Will-o'-the-wisps, the natural manifestation of the combustion of gases emitted by the dead rotting in their cemeteries, used to strike unreasoned terror into the hearts of our forebears. This dread finds psychological resonance today in the blind fear of radiation. The title of this book, Will-o'-the-wisps and Nuclear Mushrooms, is doubly intriguing, but just two paragraphs are devoted to jack-o'-lanterns; the remainder concentrates on nuclear radiation.

The authors, one French, the other American, are well-known physicists. Georges Charpak works in Geneva at the European Laboratory for Particle Physics (CERN) and in Paris, and won the Nobel prize for physics in 1992 for the design and construction of particularly efficient particle detectors. Richard L. Garwin devoted much of his talent to developing US nuclear weapons and security systems during the Cold War. President Bill Clinton has recently called on him to collaborate with Russian colleagues in reviewing strategy for the control and destruction of plutonium stocks. Charpak and Garwin therefore constitute a first-rate fount of knowledge of the civil and military applications of nuclear physics; they are a well-tuned duo in which each player is a fine soloist.

The authors begin with clear explanations of the principle of mass-energy equivalence and of the properties of neutrons.
These provide a sound basis for reflection and for the formulation of recommendations. The authors give a level-headed account, but indulge in appealing whimsy by presenting chain reactions in nuclear reactors in the form of a tragi-comedy, wittily illustrated by Sempé, the author of several collections of cartoons appreciated by young and old alike.

Having learned almost all there is to know about the neutron, the reader is introduced to the production of energy by nuclear fission using water-cooled and fast-neutron reactors. There are plenty of statistics, tables and graphs, and a demonstration that the pollution generated by the burning of fossil fuels is unquestionably greater than that caused by nuclear energy. But it is not so much pollution as the fear of accidents that is psychologically problematic.

The comparative study of the accidents at Chernobyl and Three Mile Island is revealing. In one case, human losses were great; in the other, the damage was obviously considerable but essentially financial. In both cases, human error played an important, if not major, role, and the behaviour of the "nucleocrats" scarcely helped. Was it not a Soviet official who opined after the Chernobyl disaster that "Science requires victims"?

These accidents naturally led to a resurgence of the demonizing of nuclear energy, but also, and more rationally, to renewed demands for the accurate evaluation of the effects of radiation on living matter. The granite on which our houses are built is radioactive; so too is the human body. Is there a safety threshold? And if so, where should it be set? Charpak and Garwin objectively set out the research and conclusions of those for and against. Even when the data are not filtered by those of one or other persua-

\section{Artists have felines too}

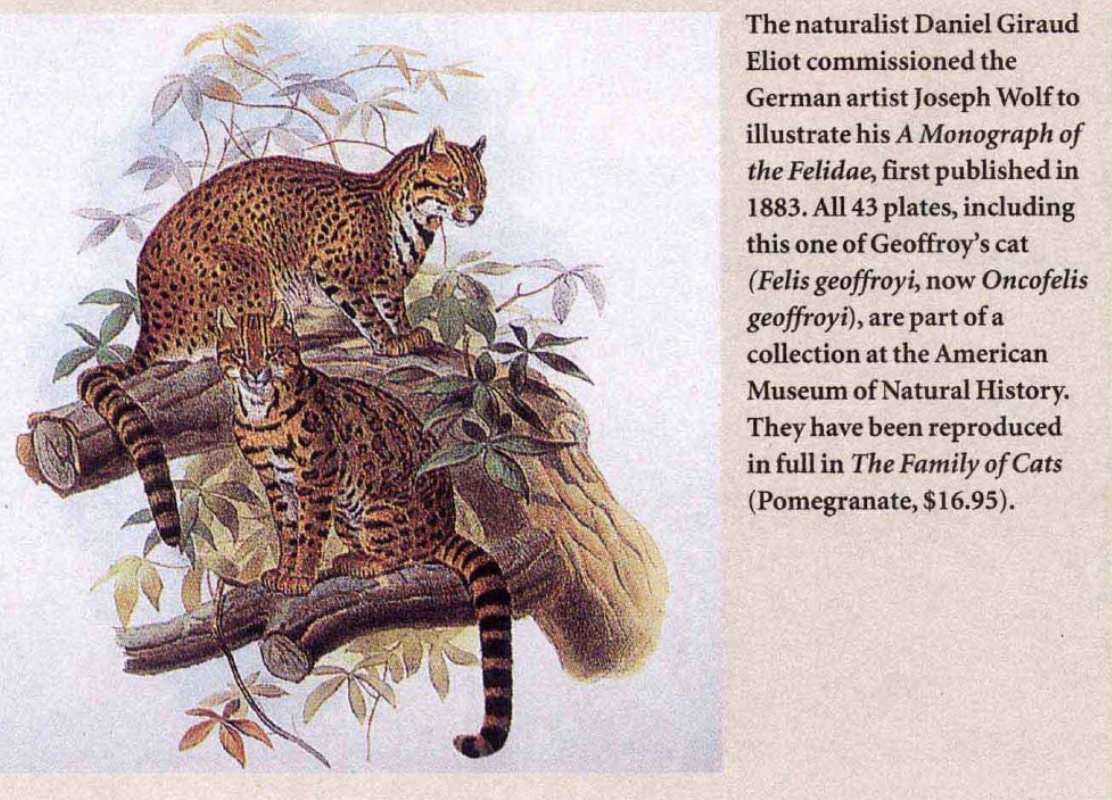

sion, considerable scope for uncertainty lingers. But we should not be tempted to salve our consciences by arguing irresponsibly that, in any case, the harm done by smoking may well exceed that caused by radiation.

Nor should we sidestep our duty to act wisely over the management of radioactive nuclear waste. No other industry has ever had to consider the consequences of its activities over a period of thousands, if not millions, of years, even if some doubtless reacted when these consequences seemed likely to impinge appreciably on natural resources or alter irreversibly the environmental balance.

The authors consider that, in the distant future, highly advanced fast-neutron reactors could provide a rational solution to the problem of waste. They also believe that new approaches to the use of energy from nuclear fission, such as that described by Carlo Rubbia with his "Energy Amplifier", are worthy of serious consideration. Rubbia proposes the use of a subcritical reactor, thereby excluding all possibility of an uncontrolled chain reaction. This reactor would be coupled to a proton accelerator in which the protons collide with lead nuclei and generate the neutrons required to trigger fission. Such a reactor would consume thorium, which is naturally more abundant than uranium, and could also use plutonium and the radioactive waste produced by other types of nuclear power stations.

"One hundred years! Give the scientists one hundred years", urge Charpak and Garwin. Scientists are now confronted by a vast field of endeavour covering optimal storage or destruction of waste, and viable alternative methods of energy production. Let us hope that these one hundred years run their course unthwarted by a global catastrophe precipitated by inept management of the Cold War legacy of some 60,000 atomic bombs!

And what of the military applications? What are the likely effects of a one-megaton bomb exploded at a height of 2,000 metres? Soviet experts considered that 600 such weapons would have been sufficient to destroy $80 \%$ of the industrial output of the United States. But the number of bombs was rationalized in terms of uncertainty about how many would penetrate the enemy's defences. Still fresh in our memories is the Strategic Defense Initiative, more popularly known as "Star Wars". Would it really have protected the United States? It certainly gave a powerful fillip to the electronics industries and, sadly, to the arms race. This point is made by the reproduction here of a particularly clear-sighted and germane article first published in 1984 by H. Bethe, R. Garwin, K. Gottfried and H. Kendall.

Can nuclear weapons be eliminated altogether? The world has entered an active phase of nuclear disarmament, but some military men and politicians still mistrust 
simple dissuasion, clinging instead to the notion of absolute protection through nuclear weapons. Charpak and Garwin propose a form of disarmament in which most nuclear warheads are rapidly scrapped and the components put into storage, while a minimal number of weapons are primed for launching. But how small is minimal?

In considering the advisability, even the necessity, of nuclear testing, slight differences emerge in the American and European viewpoints. The authors concur on specific proposals for a massive and rapid reduction in stockpiles of nuclear weapons. The United States and Russia should cut their respective arsenals to 2,000 warheads over the next two years, and the three other self-confessed nuclear powers would start scaling down their own nuclear weaponry once the American and Russian stocks descend below 1,000. A worldwide treaty could then be negotiated for the complete elimination of nuclear weapons.

The authors take as the title to their conclusion "Scientists, politicians, utopians, realists, ecologists: a common purpose". They may have cast their net wide, but who would criticize them?

Charpak and Garwin have written an excellent book in which they clearly separate comment and interpretation from information. This allows readers to learn without losing the freedom to make judgements for themselves, guided in their decisions by two trusty advocates.

Hubert Curien is the president of the Academia

Europaea, and is emeritus professor of crystallography at the University of Paris, Paris 75252, France.

\section{Gladiator for science}

\section{Huxley: Evolution's High Priest}

by Adrian Desmond

Michael Joseph: 1997. Pp. 340. £20

\section{Crispin Tickell}

This is the second part of Adrian Desmond's biography of Thomas Henry Huxley, and covers the period between 1870 and his death in 1895. It follows, rather awkwardly, from the first part (published in 1994 and reviewed in Nature 375, 300-301; 1994) as if the reader had just put the latter down and was still familiar with the cast of characters. This second part draws upon material from London's Imperial College that was not available to previous biographers.

During his life, and afterwards, Huxley was given many labels: 'Darwin's bulldog', 'Pope Huxley', 'Huxley Eikonoklastes', 'the devil's disciple' and now 'evolution's high priest'. In my view, these are misleading in different ways. During the great changes in nineteenth-century thinking about the natural world, Huxley was more of a partner to

\section{IMAGE UNAVAILABLE FOR COPYRIGHT REASONS}

'Darwin's bulldog': T. H. Huxley, painted by Alphonse Legros.

Darwin than his bulldog or disciple. He reproached himself for not having spotted the processes of natural selection, but his particular and crowning achievements lay elsewhere. More than anyone, he established the central role of science in a societyliving in an intellectual world remote from our own. Together, he and Darwin shifted the paradigm, in what was then the leading country of the world, in a fashion that can be compared with Newton's achievements almost 200 years before. Huxley did for science what others have since tried to do for the environment. The statues of Huxley and Darwin stand benevolently together in London's Natural History Museum.

Huxley was a man of amazing parts. Born in a relatively poor dissenting family, he learned how to infiltrate the ruling establishment by speaking its language and understanding its ways. Establishments rarely mind radicals if they can present themselves wearing best bib and tucker. Huxley became a member of the Athenaeum, president of the Royal Society and, eventually, a privy counsellor. In some respects, he was a conservative (with a small ' $c$ '), and suspicious of socialism and the political revolutionaries of his time.

This respectability helped him to carry out an expert demolition job on some religious beliefs, and particularly on the Church itself. Just before his death he wrote: "I am not afraid of the priests in the long run. Scientific method is the white ant which will slowly but surely destroy their fortifications." But he became something of a priest himself, not so much of evolution (as suggested in the subtitle of this book), but of agnosticism (his own word) and of an approach encapsulated in a letter he wrote in 1886: "I am too much of a sceptic to deny the possibility of anything." Thus he long held back, at least in public, from unqualified endorsement of evolution by natural selection, and described theories as "excellent servants but verybad masters".

Not least, Huxley was a creative scientist, combining detailed practical work in the laboratory with the rare gift of exposition of general ideas. Looking back, it is fascinating how far he saw ahead, predicting, for example, the role of living organisms in shaping their physical environment (now part of Gaia theory); the way that Penicillium mould stops bacterial growth; the likelihood that birds descended from dinosaurs; and the doctrine of garbage in, garbage out. As a prolific intellectual bruiser, he was without peer in his time. Woe betide those who wandered into his sights: from Bishop Wilberforce in 1860 to the ageing Gladstone in the 1880s, Huxley dealt with them in crisp and, above all, decisive fashion. He also enjoyed wide popularity. For the young H.G. Wells, he was a continuing inspiration. On Huxley's death, a dock labourer, living, as he wrote, from hand to mouth, sent a shilling postal order as a contribution to his memorial.

The role Huxley played was achieved at some personal cost. He was subject to depression and always felt driven. Until near the end, he was usually short of money. Although he was the patriarch of a happy extended family with a much-loved wife, his eldest son died in infancy, his siblings suffered a variety of misfortunes and the most talented of his daughters suffered from mental instability and died young. Any charges of immorality aimed at his thinking did not extend to his way of life. Even so, his eldest granddaughter remembered being ostracized at school for her descent from 'the great atheist', and he was the object of abuse from zealots who wrote during his last illness to rejoice in his coming prospects in hell.

Adrian Desmond brings together new information about Huxley and presents it in lively, albeit breathless, fashion. I found the best and most illuminating part occurred towards the end of the book, when Desmond seeks to place his subject in historical perspective. For the life itself, he chooses to write according to a "ciné theory of narration... a highly mediated celluloid construct, where the camera pans across a stage". I do not think this method works very well, and I hope it does not become a model for others. Too often, the result is a cross between Time magazine and television soundbites, in which continuity and coherence are lost. Clichés pile up: "the old world scornfully eyed the new"; people "chortle", "crow", "chuckle"; and so on. The book as a whole is a stock cube in need of hot water to make it digestible.

Yet it brings out facts about Huxley that are new, and there are insights of real value. It is the product of painstaking research and will itself become part of the archive. Huxley 